\title{
EDITORIAL
}

\section{Justice as care}

\author{
Christopher D. Marshall
}

Late last year, I was asked to contribute to an interdisciplinary seminar on the theme of care. Speakers were drawn from a variety of fields, ranging from nursing to geology to plant sciences to, in my case, restorative justice. Each was asked to reflect briefly on how care featured in their personal work or their academic discipline. That was probably an easier task for the social scientists on the panel, though even the physical scientists spoke eloquently of how much they cared about their research and its impact.

In pondering what I could say on the topic, my thoughts went to a book I had read recently entitled, Caring and the law, in which the author, legal scholar Jonathan Herring, proposes that the West is facing a 'crisis of care', and one that modern law is ill-equipped to deal with. This crisis has been occasioned by a range of demographic and societal changes that mean that more people are now spending longer periods of their life, either dependent on the care of others or responsible for providing care to others. Yet while the burdens of care are increasing, the resources to deliver it are diminishing.

It is not care itself that is the burden. Care is a basic human need and a fundamental social right. None of us could survive at birth or in infancy without receiving altruistic care from others in the form of food, nurture and protection, and we cannot develop or thrive thereafter as persons without the constant giving and receiving of care. Care is essential to human existence; we literally cannot live without it. But that is not something properly recognised by the modern liberal legal order or by the competitive market economy.

Care is also a fundamentally relational reality. That is to say, it necessarily takes place in the context of personal relationships that involve attachment, vulnerability, compassion, interdependence, self-giving and mutual obligation. But, Herring argues, the law prizes a different - and perhaps more stereotypically masculine - set of values to do with personal rights, autonomy, rationality, equality and freedom of choice. The law's assumed subject is the solitary, unattached, selfsufficient, individual adult male, and its chief concern is to protect his sovereign rights and freedoms from the interference of others. As Herring (2013: 46) explains:

Much of the law is based on the assumption that we are competent, detached, independent people who are entitled to have our rights of self-determination

* Christopher Marshall is The Diana Unwin Chair in Restorative Justice, School of Government, Victoria University of Wellington, New Zealand.

Contact author: chris.marshall@vuw.ac.nz. 
and autonomy fiercely protected. Legal rights and rules operate to draw boundaries around ourselves and to protect us from interference from others. However, the reality is that we are ignorant, vulnerable and interdependent individuals, whose strength and reality is not our autonomy, but our relationships with others.

In other words, contrary to prevailing liberal assumptions, human beings are not isolated, individualistic entities, rolling around society like marbles in a dish, periodically colliding with each other and choosing to enter into thin contractual relationships for purely pragmatic ends. Rather we are irreducibly social or relational beings, persons who only ever exist as part of a dense network of connections, many of which precede any choices we make in life, and from which we derive our sense of individual identity, meaning, value and moral consciousness (Pally, 2019). We are relational creatures all the way down, from the first moment of conception to the last gasp of death - and even, when you think about, beyond death (consider, for example, inheritance laws, or the ongoing genealogical links treasured so highly by indigenous communities, such as Māori, in particular).

Accordingly, far from promoting individual freedoms and self-reliance, the law ought to be designed to encourage, enable and maintain caring relationships. Rather than being based on a set of abstract moral principles and dispassionate rules, legal procedures should be grounded on the primacy of human interconnectedness and on the rights and duties that flow from such connections, ever cognizant of the fact that no one can survive, let alone flourish, without the existence of caring relationships with others. 'We can only produce a coherent model of justice', Herring (2013: 67) observes, 'if we start with the norm of people existing in interlocking relationships, because that is the reality of people's lives'. Legal institutions, and society as a whole, would look very different if they were based on the principles of relational care rather than on the ideal of the competitive, self-sufficient, unattached, able-bodied, adult male protagonist.

Herring is by no means alone in this diagnosis. He draws heavily on the socalled 'ethics of care' literature, an approach to moral theory whose origins are usually attributed to the works of psychologist Carol Gilligan (1982) and philosopher Nel Noddings (1984) in the mid-1980s, and further developed by a range of influential, typically feminist, thinkers. There is now a substantial literature in which care ethics has been applied to a wide range of moral, social and political problems. As the field has grown in scope and ambition, it has, unsurprisingly, encountered criticism and sparked divergences of opinion. Critics have pointed, for example, to ambiguities surrounding the definition of care and its normative status. Many have challenged the gendered assumptions or perceived essentialism at work in the theory. Some have argued that prioritising relational care only serves to underwrite the subservience of women and other underprivileged groups in society by rendering domestic servitude as a value. Others have objected to the tendency to set relational obligation in tension with core liberal values of personal autonomy and individual rights (Sander-Staut, 2019).

A particular point of debate has been the relationship between care ethics (focused on trust, empathy, mutuality, obligation and responsiveness to need) 
and justice ethics (based on rights, equality, impartiality, fairness and freedom). Initially care theorists regarded these two approaches to moral reasoning as mutually exclusive, but increasingly they are viewed as complementary undertakings (Held, 2006; Friedman, 2008). While demurring from the liberal preference for universal, rule-based abstraction over actual embodied experience and contextual sensitivity, most care ethicists accept the importance of integrating care into a larger framework of social justice to ensure that the distribution and practice of care are not arbitrary or capricious. For care unconstrained by external standards of fairness and equality is liable to parochialism or prejudice. At the same time, law, policy and procedures should be designed to encourage and sustain caring relationships between citizens, not simply to protect private entitlements.

There are specific challenges when it comes to reconciling care with the coercive functions of the state, such as the criminal justice system or in aspects of the welfare system. On the one hand, there is the risk of the state claiming the motive of care to justify excessive or prolonged interventions in the lives of individuals in the name of treating their dysfunctions or rehabilitating them in society, or, conversely, of minimising personal responsibility by appealing to underlying disorders. In both cases, the principle of equal justice is compromised (Marshall, 2001: 99-104). On the other hand, there is the danger of the language of care being used to disguise the retributive or political interests of the system, such as describing prison inmates as those 'in care' rather than those under sentence of punishment. There is also a propensity for the state to co-opt alternative justice practices as a way of relieving pressure on the retributive system so that it does not collapse under its own weight, thereby using therapeutic interventions to enable rather than fundamentally humanise a harmful system.

Clearly, then, a rule-based justice system is not a natural site for relational care to operate. But, as I argue in Compassionate justice (2012: 249-322), if public institutions can be cruel, as few would deny, potentially they can also be compassionate or caring, not by feeling compassion as an emotion but by striving to observe the principles and obligations of care in the way they operate (Unwin, 2018).

\section{Restoring care}

In describing what 'care' entails, Herring identifies four essential markers of its presence: it meets human needs; it expresses respect for the dignity of the recipient; it accepts responsibilities for addressing disadvantages; and it creates relationships of reciprocity, in which the interests of the carer and the interests of the cared for are inextricably united. A caring relationship is not necessarily an affectionate relationship, but it is always one that enables and empowers both parties and that affirms the equal worth of each.

Significantly, these are precisely the same identifying characteristics of restorative justice practice (Herring himself does not make this connection, since his focus is on medical law and family law, but I am sure he would appreciate the link if it were pointed out to him). As an approach to law and justice, restorative 
justice focuses squarely on addressing human needs; it acknowledges the equal dignity of all parties, irrespective of their role in the harmful act; it accepts responsibilities for addressing the disadvantages or inequities that crime has bequeathed to victims and that often have contributed to offending on the part of the perpetrator; and it derives its creative potential from the shared vulnerability and reciprocal exchange of concern that occurs through respectful face-to-face encounter. Restorative justice constitutes a relational justice of care, and as such may be seen as an example of the kind of legal transformation Herring considers necessary if the legal system is to address the growing void of care and clawing loneliness at the heart of modern society.

Not everyone will agree with this way of construing restorative justice. Scholars continue to debate how best to define or capture the essence of restorative justice. Some definitions focus on its distinguishing dialogical practices or procedures; others emphasise its undergirding values or philosophical precepts; still others highlight its reparative or transformative aspirations, whether at a personal or political level. There are also differences over whether the definition should be limited to criminal justice applications alone or be inclusive of the broader range of restorative practices used in schools and workplace settings, family and human services, community development initiatives, and in intercommunal peacemaking and transitional justice processes.

Of course, academic debates over the semantics of restorative justice still presuppose there is something novel there worth naming, something descriptively distinctive about a restorative way of framing or responding to societal harms, something that sets it apart from the more familiar adversarial or therapeutic ways of doing so. How best to capture this difference - this restorative ethos - is debatable, but the need to try to do so seems obvious, not least for the purposes of promoting wider awareness of the approach.

To my mind, the distinctiveness of restorative justice lies in its peculiar combination of processes, values and intended outcomes, so that any description or proposed definition of restorative justice ideally should include all three elements. In explaining the approach to others, as I do on an almost daily basis, I usually depict restorative justice as a relational way of responding to criminal wrongdoing or similarly harmful episodes, whereby those with a personal stake in the harm come together, in a safe and respectful environment, usually with the help of skilled facilitators, to speak truthfully about what happened and its impact on their lives, to clarify accountability for the damage that has occurred, and to resolve together how best to promote repair and bring about positive changes for all involved.

Each phrase invites unpacking, but the virtue of this formulation is that it combines the distinctive process of restorative interventions (a facilitated dialogue between those directly involved in harmful events), its undergirding relational values (including freedom of choice, respectful communication, truthfulness, accountability and equal concern), and the envisioned goals or outcomes of the practice (the clarification of what happened in the past and its human impact, and collaborative decision-making about how best to promote repair and achieve positive changes for all involved). The goal of repair is particularly significant to 
highlight. Ross London (2011: 24; Marshall, 2015) has argued this goal represents a new departure in criminal justice thought and practice.

Whereas the traditional goals of the criminal justice system are to deter, censure, incapacitate, and rehabilitate offenders, restorative justice poses an entirely new and original goal: repairing the harm of crime.

Put differently, while retributive justice focuses chiefly on the crucial but limited goals of establishing the truth about criminal responsibility and holding perpetrators publicly accountable, restorative justice adds the additional goal of repairing or healing the damage done by the crime, insofar as that is achievable. Such a reparative or transformative aspiration exemplifies its quality as a relational justice of care, particularly when we think of care, not primarily as a feeling, but, in the words of care theorist Joan Tronto (2015: 3), as 'a species of activity that includes everything we do to maintain, continue, and repair our world, so that we may live in it as well as possible.'

Admittedly there are critics who recoil from any talk of justice as healing or any attempt to confound justice and love. They dismiss such therapeutic and affective language as sentimental and simplistic, or even as unscrupulous, given how mystifyingly difficult healing is to achieve in practice or to measure, and how easily recuperative or psycho-social aims can compromise or eclipse the moral requirement for accountability and rightful denunciation (Acorn, 2004; Borton \& Paul, 2015)). The demands of justice and the goal of healing, they insist, should be kept separate, and if restorative justice is to be taken seriously, it must be focused normatively on the former, not the latter.

But there are both theoretical and empirical grounds to challenge this objection. Philosophically, while justice and love are not identical values, they are mutually dependent and cannot be hermetically sealed off from each other, for any attempt to achieve justice without the filter of love will be deficient at best and dangerous at worst (DeValve et al., 2018; Jackson, 2003; Bell, 2007). Empirically, if restorative justice has taught us anything, it is that victims of crime only begin to feel that justice is being accomplished when their needs for repair - both substantive repair and especially moral repair - have been addressed in some appreciable way (Walker, 2006; Johnstone, 2019). As well as truth telling and accountability, they crave recovery, and all three requirements feed a primitive drive for a justice that restores their wellbeing. Offending has injured them at their spiritual and relational core; it has denied their inherent dignity and trampled on their rights and feelings, as though these things do not really matter. Justice therefore requires the mending or healing of these visceral injuries, otherwise it remains partial at best and re-victimising at worst. As John Braithwaite is fond of saying, because crime wounds, justice must heal, as long as justice is understood relationally (Braithwaite, 2002: 80; Piquero \& Mazerolle, 2011).

This is something the punitive justice system largely fails to deliver, because punishment does little or nothing to heal, either the offender or the victim. Long ago, George Bernard Shaw (1961: 26) put his finger on the problem of punishment for offenders. 'If you are to punish a man retributively', he wrote, 'you must 
injure him. If you are to reform him you must improve him. And men are not improved by injuries'. The problem for victims is even greater. A justice system that devotes almost all its energies and resources to denouncing and penalising offenders has little left over for victims - as victims soon discover, usually to their surprise and horror, when they enter the portals of the system looking for something that will validate their losses and restore their wellbeing. If this is ever to happen, they need an experience of justice that is not only motivated by care (as is the retributive system, which cares legitimately about upholding the law and thereby protecting citizens), but also that delivers care in practice, a justice characterised by the four markers of care identified by Herring: a focus on meeting needs; an upholding of the inherent dignity of all parties; a shouldering of responsibility to address vulnerability and harm; and, above all, by a concern to restore relationships to a just condition, that is to one in which both sides recognise the rights, dignity, equality, agency and legitimate interests of the other.

This is the standard of care restorative justice should aspire to achieve and against which it should be measured. By viewing the harm of crime as fundamentally a failure of relational care and trust, it follows that what makes restorative responses to offending potentially so significant for the participants, and for society at large, is that they furnish the conditions where relational trust can begin to be restored, mutual care expressed and healing fostered through concrete acts of responsibility and repair.

\section{Some implications}

At one level, this characterisation of restorative justice as a distinctively carefocused approach to justice is a relatively innocuous claim. It simply makes explicit what practitioners intuitively know to be true in practice. It is also not a novel suggestion. Other writers have appealed to the ethics of care to account for the distinctiveness of restorative justice in comparison to the mainstream system. For example, writing twenty years ago, Masters and Smith (1998: 15-16, 20) argued that by forging a connection between restorative processes and the feminist ethics of care, 'we can think of relational justice as "caring justice", or even (dare we say?) "loving justice".' They even go on to deem Braithwaite's theory of reintegrative shaming as 'perhaps the first feminist criminological theory', a claim roundly rejected by Kathleen Daly (2010: 291-294) for its gender stereotyping and dichotomous assumptions.

Liz Elliott (2010: 48-65) has also appealed to care ethics to explain why restorative justice, which is 'predicated on values of care and attachment', is illsuited to operate within a corrections system predicated on detachment, separation and mistrust. Such institutional values make prison environments structurally antithetical to fostering caring or nurturing relationships, which by definition require vulnerability, interdependence, needs-meeting and mutuality, qualities perceived by prison authorities to pose a positive risk to security.

Yet despite the obvious congruence between care principles and restorative justice, 'care' is still a relatively under-utilised idiom in the restorative lexicon, as 
a quick check of the indices of the major handbooks and collected works that serve our field indicates, even while the dynamics of care are prodigiously evidenced throughout these works. This suggests that one benefit to come from conceptualising restorative justice as a relational justice of care would be to elevate care, and its associated qualities of vulnerability, reciprocity and relational personhood, from a contingent feature of practice to a theoretical concept, with the ability to deepen our appreciation for how and why restorative justice works, its ontological presuppositions, and how it relates to the larger enterprise of building an inclusive and responsive democracy (Montellanos, 2016).

Theo Gavrielides (2019: 499) has recently observed that,

if restorative justice is to be further normatively developed and its practices expanded, then we must do so by placing its caring aspect at the centre of our attention ... Non-believers in the existence of this inherent caring element of the restorative justice matrix will struggle to understand, theorise, legislate or implement it.

Gavrielides goes on to express fear for the impact on victims and offenders of being offered an 'uncaring restorative justice', that is, one in which laws, policies and practices prioritise power over care. He considers this to be a worrying trend in the recent movement.

Perhaps restorative justice is more prone to this danger than are parallel practices in schools and workplaces. This is because, in the criminal justice sphere, restorative justice remains an essentially reactive mechanism for addressing offences that have already occurred. It is prized primarily for its potential to resolve such cases satisfactorily, not for its power to transform the institutional culture of the broader justice system. In the case of schools, however, there is a growing emphasis on the proactive use of restorative tools to 'foster a culture of care, inclusion and equity' in the larger school community (Bevington \& Gregory, 2019: 182). In many cases, restorative practices are more highly valued in schools for their ability to promote culture change than for resolving episodes of misconduct. Arguably, the extent to which restorative justice is perceived to be just another behavioural management tool within a dominant system of social control and punishment is the extent to which it risks substituting power for care.

To construe restorative justice as a relational justice of care also has implications for how success should be measured. There is now a substantial body of research available assessing the impact of restorative justice. But the most common measures used - such as reduced rates of reoffending, victim satisfaction with the process, reduced costs to the system, and so on - are more reflective of the goals of the mainstream justice system than of the underlying philosophy of restorative justice itself. Even attempts to measure the 'restorativeness' of particular programmes tend to focus more on the procedural dynamics of the process than on the larger societal and relational transformations the practice encourages. But if restorative justice is truly an approach that seeks to promote right relationships - that is, relationships marked by equality, dignity, respect, trust and a mutuality of care and concern - then we need to develop measures that 
reflect that relational goal (Llewellyn, 2012; Llewellyn et al., 2013; Llewellyn \& Philpott, 2014). These might include attempts to assess its impact on the network of relationships implicated in the harm; its contribution to the development of collaborative peacemaking skills and values in the affected community; the degree to which it enhances the participants' ongoing commitment to other relational obligations, both personal and public; and its role in fostering activities of care intended to 'maintain, continue, and repair our world, so that we may live in it as well as possible' (Tronto, 2015: 3).

Accentuating the priority of relational care has implications, finally, for the institutionalising or mainstreaming of restorative justice, that is, for attempts to incorporate it into the formal justice system, subject to administrative and fiscal oversight and accountable to professional standards of practice (Aertsen et al., 2006; Woolford, 2009). I have already commented on the peculiar challenges of institutionalising care and compassion, and the tendency of bureaucratic systems to co-opt or corrupt caring commitments in service of achieving other performance indicators. This means that framing restorative justice as a relational justice of care serves to focus, rather than resolve, the problem of how its care-based ethic and practices can be sustained within a system devoted to risk management, cost efficiency and predictability. There are no simple answers to this dilemma and possibilities will vary from place to place. But it is worth noting there are several points in the existing system where care-considerations already play a tacit role, such as in sentencing decisions or victim assistance programmes or in the way therapeutic courts operate, and where restorative processes can be employed to enhance the depth of relational engagement and quality of care involved.

\section{Concluding thoughts}

To speak of restorative justice as a relational justice of care is not to say such care is a simple or straightforward thing to achieve. Care is complicated. As well as being a source of meaning and fulfilment in life, it is also often messy, ambiguous, frustrating, challenging, exhausting and personally costly - just as human relationships are. Yet without the mutuality of care, it is impossible to develop meaningful relationships with others or to restore relationships to their rightful or just condition when harm has occurred.

Not long ago, I facilitated a restorative justice conference in prison between a young man who was nearing the end of a sentence for reckless driving causing death, and the parents and siblings of the teenager who had been killed in the accident. The young man had stolen a car one evening and picked up his best friend for a joy ride, but he crashed the vehicle and his friend died in the collision. The deceased boy's parents had come down to the city where the prison was located in order to attend a Parole Board hearing later in the week, at which they intended to oppose the driver's application for parole after completing two-thirds of his sentence. They opposed his release because they were convinced that he had shown no signs of remorse and did not care about what he had done. 
Among the reasons they gave for this judgment was the way the young offender had behaved at court several years earlier prior to sentencing - chewing gum, with his hoodie pulled up and swaggering like 'he didn't give a shit', as his victim's father put it. The parents wanted to meet the offender in prison before the parole hearing, mainly to get answers to questions about the accident that continued to torment them. They also decided, to my considerable consternation, to bring the ashes of their dead son into the prison with them in a hand-painted urn, 'to show him what he had done', as his mother explained to me on the phone the night before.

It would take a long time to explain all that transpired during this remarkable conference and why the parents of the victim ended up going to the parole hearing the next day to argue in favour of the release of the driver (to his lawyer's astonishment). But essentially their change of attitude came down to the realisation at the conference of how deeply the young man did care about the friend he had killed, as well as the explanation he gave for why he had appeared so nonchalant at court (he explained that he was back on drugs at the time, trying to numb his feelings of guilt and shame, and that he avoided any eye contact with his victims for fear he would fall apart).

There are two memories from that conference that will remain with me for a long time, as testament to the restorative power of care. One was the way the mother of the victim, at the conclusion of the meeting, embraced the boy responsible for her son's death, just before he was led away to his cell. She did not just hug him. She held him in her arms, as if he were her own child, for what seemed like an eternity. The other was the way the young man, before leaving the room, picked up the brightly painted urn containing the ashes of his dead friend and cradled it against his chest to say farewell to him, with a dignity and sincerity that swept away all traces of suspicion that he 'didn't give a shit'. It was a spontaneous and deeply moving gesture that probably did more to bring healing to the victims than anything the legal system could offer.

The conference had been a logistical nightmare to organise on a cold winter evening and had stretched my practitioner skills almost to breaking point. But those two displays of reciprocal care made it all worthwhile and confirmed again, for me, the value of conceptualising restorative justice as a transaction of relational care from which it derives its unique power and significance.

\section{References}

Acorn, A. (2004). Compulsory compassion: a critique of restorative justice. Vancouver: University of British Columbia Press.

Aertsen, I. Daems T . \& Robert L. (eds.) (2006), Institutionalizing restorative justice (pp. 261-281). Cullompton: Willan Publishing.

Bell, R.H. (2007). Rethinking justice: restoring our humanity. Lanham: Lexington.

Bevington, T. \& Gregory, A. (2019). Restorative practice as peace practice. In M. Thorsborne, N. Riestenberg \& G. McCluskey (eds.), Getting more out of restorative practice in schools: practical approaches to improve school wellbeing and strengthen engagement (pp. 181-193). London: Jessica Kingsley Publishers. 
Borton, I.M \& Paul, G.A. (2015). Problematizing the healing metaphor in restorative justice, Contemporary Justice Review, 18(3), 257-73.

Braithwaite, J. (2002). Restorative justice and responsive regulation. New York: Oxford University Press.

Brien, A. (1998). Mercy within legal justice. Social Theory and Practice, 24, 83-110.

Daly, K. (2010). Restorative justice: the real story. In C. Hoyle (ed.), Restorative justice: critical concepts in criminology (Vol. 1, pp. 281-308). London: Routledge.

DeValve, M.J., Garland, T.S. \& Wright, E.Q. (2018). A unified theory of justice and crime: justice that love gives. Lanham: Lexington Books.

Elliott, L. (2010). Security, without care: challenges for restorative values in prison. In C. Hoyle (ed.), Restorative justice: critical concepts in criminology (Vol. 2, pp. 44-65). London: Routledge.

Friedman, M. (2008). Care ethics and moral theory: review essay of Virginia Held, 'The ethics of care'. Philosophy and Phenomenological Research, 77(2), 539-555. doi:10.1111/j. 1933-1592.2008.00205.x.

Gavrielides, T. (2019). Restorative justice with care and responsibility: new directions in restorative justice theory, practice and critical thinking. In T. Gavrielides (ed.), Routledge international handbook of restorative justice (pp. 488-503). London: Routledge.

Gilligan, C. (1982). In a different voice: psychological theory and women's development. Cambridge: Harvard University Press.

Held, V. (2006). The ethics of care: personal, political, and global. Oxford: Oxford University Press.

Herring, J. (2013). Caring and the law. Oxford: Hart Publishing.

Jackson, T.P. (2003). The priority of love: Christian charity and social justice. Princeton: Princeton University Press.

Johnstone, G. (2019). Restorative justice and the therapeutic tradition. In T. Gavrielides (ed.), Routledge international handbook of restorative justice (pp. 395-408). London: Routledge.

Llewellyn, J.J. (2012). Integrating peace, justice and development in a relational approach to peacebuilding. Ethics and Social Welfare, 6(3), 290-302. doi: 10.1080/17496535.2012.704386.

Llewellyn, J.J. \& Philpott, D. (2014). Restorative justice, reconciliation and peacebuilding. Oxford: Oxford University Press.

Llewellyn, J.J., Archibald, B.P., Clairmont, D. \& Crocker, D. (2013). Imaging success for a restorative justice approach to justice: implications for measurement and evaluation. Dalhousie Law Journal, 36(2), 281-316.

London, R. (2011). Crime, punishment, and restorative justice: from the margins to the mainstream. London: FirstForum Press.

Marshall, C.D. (2001). Beyond retribution: a New Testament vision for justice, crime and punishment. Grand Rapids: Wm B. Eerdmans.

Marshall, C.D. (2012). Compassionate justice: an interdisciplinary dialogue with two gospel parables on law, crime, and restorative justice. Eugene: Cascade Press.

Marshall, C.D. (2015). Restoring what? The practice, promise and perils of restorative justice in New Zealand. In W. Brookbanks (ed.), Therapeutic jurisprudence: New Zealand perspectives (pp. 147-160). Wellington: Thomson Reuters.

Masters, G. \& Smith D. (1998). Portia and Pereshone revisited: thinking about feeling in criminal justice. Theoretical Criminology, 2(1), 5-27. doi: 10.1177/1362480698002001001.

Montellanos, A. (2016). Care in restorative justice (MA thesis in philosophy). San Diego: San Diego State University. 
Noddings, N. (1984). Caring: a feminine approach to ethics and moral education. Berkeley: University of California Press.

Pally, M. (2019). Relational view of humanness: the reciprocity of ontos and telos. Studies in Christian Ethics, 1-11. doi:10.1177/0953946819847958.

Piquero, N.L. \& Mazerolle, P. (2011). Because crime hurts, justice must heal: John Braithwaite. In A. Myer (ed.), The origins of American criminology: advances in criminological theory (pp. 261-273). New Jersey: Transaction Publishers.

Sander-Staudt, M. Care ethics. Internet Encyclopedia of Philosophy, ISSN 2161-0002. Retrieved from https:/www.iep.utm.edu/ (last accessed 10 April 2019).

Shaw, G.B. (1961). The crime of imprisonment. New York: Citadel Press.

Tronto, J.C. (1993). Moral boundaries: a political argument for an ethic of care. New York: Routledge.

Tronto, J.C. (2015). Who cares? How to reshape democratic politics. Cornell University Press.

Unwin, J. (2018). Kindness, emotions and human relationships: the blind spot in public policy. Dunfermline: Carnegie UK Trust. Retrieved from https://www.carnegieuktrust. org.uk/publications (last accessed 10 April 2019).

Walker, M.U. (2006). Moral repair: reconstructing moral relations after wrongdoing. Cambridge: Cambridge University Press.

Woolford, A. (2009). The politics of restorative justice: a critical introduction. Halifax: Fernwood Publishing. 